Maciej Mikulski

Mgr inż.

Zarząd Transportu Publicznego w Krakowie

mmikulski@ztp.krakow.pl,

m_mikulski@vp.pl

DOI: 10.35117/A_ENG_21_06-07-08_03

\title{
The efficiency of the fare-free public transport for the air pollution reduction
}

\begin{abstract}
The article presents the problem of air pollution in polish cities on the example of Cracow. The focus was on one of the corrective actions taken by the city - free-fare public transport during high air pollution. Changes in the city's approach to this service since 2015 and consequences for the city budget were presented. Then, the efficiency of free-fare public transport in attracting new passengers was considered. The example of the Nysa town was cited, which introduced such permission for car drivers, but withdrew it three years later. In the next step, the concentration of air pollution before and after the activation of free-fare public transport in the heating season 2018/2019 was analyzed. Particulate matter PM10, nitrogen oxide and carbon monoxide were taken into account. There was no constant relationship between the changes in the level of these pollutants in the air and the full-paid (or fare-free) public transport. There is also no reason for the need to change parameters based on witch the fare-free public transport is activated. Finally, the necessity of further efforts of central and local authorities to improve air quality as well as further research on sources of air pollution and efficiency of undertaken actions was emphasized.
\end{abstract}

Keywords: fare-free public transport, air pollution, environmental protection

\section{Introduction}

The condition of air quality in the city of Cracow and the agglomeration should be assessed negatively. The city is classified as one of the most polluted in Poland [10]. The limit levels for Particulate matter PM10, the target level for benzo (a) pyrene and the limit for nitrogen dioxide [1] are regularly exceeded. One of the reasons for this is the topography - the city's location in the Vistula valley and the specific climatic realities associated with it: frequent temperature inversions, pools of cold air, the greater number of atmospheric silences and weak winds [1]. As a result, conditions have created that favour the accumulation of pollutants. The situation is particularly dramatic on windless days with high air humidity. Figure 1 shows Dietla Street in Cracow during high air pollution.

The increase in concentrations of PM10, PM2.5 and benzo (a) pyrene occurs during the heating season because the main source of these pollutants is the so-called low emissions (combustion of coal and derivatives in domestic furnaces) [1]. Transport, in turn, is the main source of emissions of carbon monoxide and nitrogen oxide $[1,10]$. In this case, no seasonality of concentration levels is observed, but their accumulation occurs pointwise in the areas of intersections and main communication arteries [4].

One of the remedial actions taken by Krakow was the introduction in December 2015 of a free- fare public transport service during high air pollution - as an incentive for drivers to leave their cars and use public transport in order to reduce emissions from transport. 


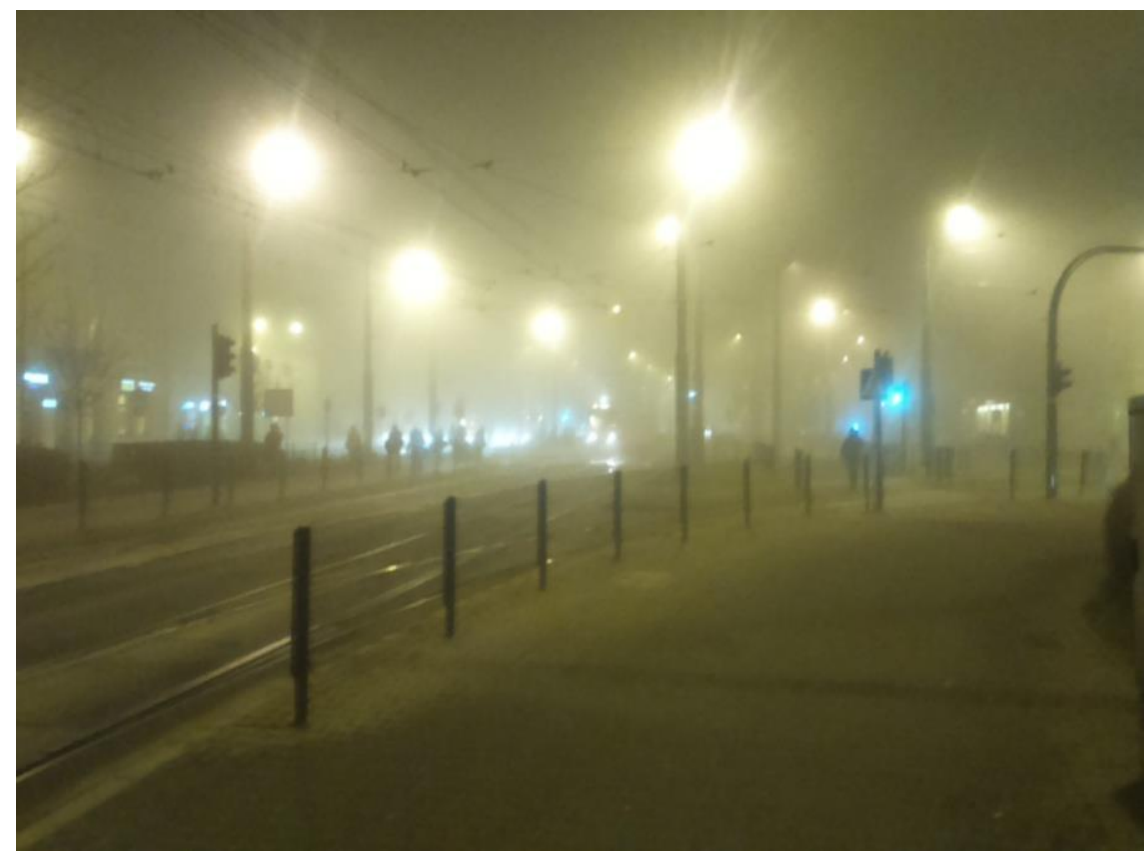

1. Dietla Street in Cracow during high air pollution

\section{Air quality monitoring}

Air quality is monitored by the Regional Inspectorate for Environmental Protection (WIOŚ) [4]. Currently, there are 8 measuring stations in Cracow [5]. Their locations and selected measured parameters (marked with the letter "x") are presented in Table $\mathbf{1}$.

Measurements are carried out using two methods: automatic and manual [5]. Automatic measurement is based on the use of gas analyzers, selective for a specific type of pollutant [5]. Air is supplied to the device, which is then analyzed using various methods for the presence and concentration of appropriate pollutants [5]. The measurement is performed continuously [5]. Manual measurement is based on the use of aspirators, in which pollutants are separated by means of selective filters or scrubbers absorbing specific substances [5]. The samples are transported to the laboratory and analyzed there [5]. The disadvantage of manual measurement is the extended waiting time for the results.

Tab. 1. Locations of measuring stations in Cracow and measured parameters. Source: own study based on [5]

\begin{tabular}{|l|c|c|c|c|}
\hline location / parameter & PM10 & PM2,5 & $\begin{array}{l}\text { nitrogen } \\
\text { oxide }\end{array}$ & $\begin{array}{l}\text { carbon } \\
\text { monoxide }\end{array}$ \\
\hline Krasiński Avenue & $\mathrm{x}$ & $\mathrm{x}$ & $\mathrm{x}$ & $\mathrm{x}$ \\
\hline Piastów estate & $\mathrm{x}$ & & & \\
\hline Swoszowice estate & $\mathrm{x}$ & & & \\
\hline Wadów estate & $\mathrm{x}$ & & & \\
\hline Złoty róg Street & $\mathrm{x}$ & & & \\
\hline Kurdwanów Street & $\mathrm{x}$ & $\mathrm{x}$ & $\mathrm{x}$ & \\
\hline Dietl Street & $\mathrm{x}$ & & $\mathrm{x}$ & \\
\hline Nowa Huta & $\mathrm{x}$ & $\mathrm{x}$ & $\mathrm{x}$ & $\mathrm{x}$ \\
\hline
\end{tabular}

Rules for launching fare-free public transport in Cracow during high air pollution

Entitlements to fare-free travel by means of public transport in Cracow and the agglomeration (municipalities that have joined the agreement in order to jointly implement public collective transport) in the period with forecasted exceedances of certain air quality standards are granted 
by Resolution No. XXXIV / 578/15 of the Cracow City Council of 16 December 2015 as amended [7]. Currently, in accordance with the provisions of the above-mentioned resolution, free communication is introduced when the daily air quality forecast of the Institute of Meteorology and Water Management (IMWM) for the next day, dedicated to the Municipality of Cracow, indicates the probability of exceeding the average levels of PM10 dust concentrations in any two of the three 8-hour intervals of the day simultaneously [7]:

1. above $100 \mu \mathrm{g} / \mathrm{m}^{3}$, in the area of the City of Cracow equal to or greater than $50 \%$,

2. above $150 \mu \mathrm{g} / \mathrm{m}^{3}$, in the area of the City of Cracow equal to or greater than $50 \%$.

If the forecast does not meet the above-mentioned conditions, and the average of measurements from all measuring stations located in Cracow will indicate PM10 dust exceeding $150 \mu \mathrm{g} / \mathrm{m}^{3}$ on the next day, fare-free communication is launched - starting from the first morning route (daily [7].

In the event of the above-mentioned circumstances, the transport organizer (Public Transport Authority) receives information from the Crisis Management Center of the City of Cracow (CZK) about the fulfilment of the criteria for launching free communication for the next day, and then the service is implemented, and passengers are informed about this fact on the pages of websites, social networks, passenger information boards and messages inside buses and trams. It should be noted here that in no case the launch of fare-free public transport is discretionary or dependent on the transport organizer, who is only the implementer of the above-mentioned resolution of the Cracow City Council. Air quality forecasts are carried out by the Institute of Meteorology and Water Management.

\section{History of the fare-free public transport service}

Since the introduction of fare-free public transport during high air pollution (December 2015), the service has been launched 29 times, as detailed in Table 2.

Initially, free public transport was launched on the basis of PM10 concentration readings. If the level exceeds $150 \mu \mathrm{g} / \mathrm{m}^{3}$ - calculated as the average result of measurements for a given day, as at 4:00 p.m., or above $200 \mu \mathrm{g} / \mathrm{m}^{3}$ - calculated as the average result from one measuring station located in Cracow, for the same hour, then, on the next day, the person presenting the registration certificate of the passenger car with accompanying persons was entitled to free travel - in total in the number consistent with the entry specifying the number of seats in the car [7]. In cases where the average was close to the limit levels and the weather forecast for the next day did not give clear grounds for introducing free transport, it was permissible to use the 18-hour average for the final decision making [7].

Then, in October 2016, the first condition was clarified - the average was calculated from 01:00 to 4:00/5:00 p.m. and the record with an average of $200 \mu \mathrm{g} / \mathrm{m}^{3}$ was deleted [7]. Instead, the second option was to launch free public transport based on the average between 12.00 a.m. - $10.00 / 11.00$ p.m. The required concentration remained unchanged $-150 \mu \mathrm{g} / \mathrm{m}^{3}$ [7]. As a result of this change, an employee of the then Municipal Infrastructure and Transport Board had to be alerted to any news about the implementation of the procedure in the middle of the night (information was received with an hour delay). Likewise, most passengers did not find out about free transport until the morning, after leaving their homes, or even after their first trip. Only the holders of registration certificates remained unchanged.

In December 2017, fundamental changes to the procedure for launching fare-free public transport were adopted. Instead of the readings, they were based on the forecasts described earlier, arguing that the free communication based on measurements was not triggered until the next day, so the response to poor air quality was delayed. In July 2018, due to the multiple discrepancies in forecasts with the subsequent actual state of air pollution, it was additionally possible to introduce free travel from the first morning runs based on the PM10 readings at 3:00 am. The "hybrid" rules satisfied the arguments of enthusiasts of both earlier procedures. At the 
same time, the range of addressees of the service was extended to include all passengers - the necessity to present a registration certificate was abandoned. On the one hand, it was a response to the social pressure of people who felt aggrieved by the fact that free city transport was only for drivers, on the other hand, a new problem arose - claims of season ticket holders who do not receive compensation for the days of validity of their subscriptions on which other people can travel by buses and trams without payment.

Tab. 2. Days of fare-free public transport in Cracow during the high air pollution. Source: own study based on data from the Public Transport Authority in Cracow

\begin{tabular}{|l|l|l|}
\hline year & $\begin{array}{l}\text { number of } \\
\text { days }\end{array}$ & comments \\
\hline 2015 & 0 & \\
\hline 2016 & 2 & only for holders of registration certificates \\
\hline 2017 & 18 & only for holders of registration certificates \\
\hline 2018 & 7 & $\begin{array}{l}\text { 3 days (Q1) only for registration certificate holders } \\
\text { 4 days (Q4) according to the new rules (rights for all passengers, } \\
\text { not only for holders of registration certificates) }\end{array}$ \\
\hline 2019 & 2 & including 1 day based on morning measurements \\
\hline 2020 & 0 & state until the beginning of March \\
\hline
\end{tabular}

\section{Budgetary Consequences}

In the context of the burden on the budget of the City of Cracow, launching fare-free public transport during high polluted air does not constitute increased costs of its operation, because the Public Transport Authority pays operators (Miejskie Przedsiębiorstwo Komunikacyjne and Mobilis) for the completed car and train-kilometers, the number of which does not change for this reason. [9]. When the last draft of the amendment to the resolution on free travel by public transport (June 8, 2018) was submitted to the deliberations of the Cracow City Council (June 8,2018 ), it was estimated that the establishment of this type of rights may result in the failure to obtain possible revenues from the sale of validation tickets in the amount of approximately PLN 335,000 for each day the validity of the entitlement [9]. It should be noted, however, that in this case, it is not possible to determine the exact amount, as the daily number of passengers is variable and susceptible to a number of factors, such as weather, day of the week or occasional events.

\section{Effectiveness of fare-free public transport in attracting new passengers}

In 2013, the inhabitants of Cracow indicated low costs as the fourth main reason for choosing buses and trams during journeys (21.6\% of responses) [2]. At the same time, only $0.1 \%$ of respondents in the same question indicated a high price of fuel or parking lots [2]. It can therefore be concluded that, on the one hand, low ticket prices are an incentive, but, on the other hand, high fuel or parking prices do not deter the use of private cars. On the other hand, among the 10 criteria for assessing Cracow's urban public transport, the cost of travel was indicated only in eighth place [2]. Therefore, there is a doubt whether drivers will actually leave their own or company car for public transport just because they are offered this service free of charge? And if the answer is overwhelmingly negative, will the awareness of the pro-ecological nature of such behaviour also outweigh the scales?

The downward trend in the attractiveness of public transport, which becomes a good of lower utility, to the benefit of the individual, is an attribute of modern society, which results from the income elasticity of demand [8]. Demand for collective transport services is declining while income is increasing [8]. After reaching the appropriate standard of living, the cost of travel ceases to play a significant role in the process of choosing a means of transport. This is 
evidenced by the attitude of the city of Nysa, which in May 2012 introduced free public transport for car owners on the basis of a valid registration certificate, but in August 2015 it gave up this solution due to low effectiveness in influencing the transport preferences of residents [8].

Therefore, the lack of payment for public transport is not a sufficient incentive for most drivers to leave their cars and change the means of transport from individual to collective. However, it is also an unfavourable incentive to substitute active mobility, which may significantly affect the total increase in the number of passengers.

Comparison of air pollution before and after the introduction of fare-free communication For the purposes of this study, the focus was on the measurements carried out using the automatic method. The 2018/2019 heating season was taken into account, from which fare-free communication was addressed to all passengers, not only those with a passenger car registration certificate. At that time, hypothetically, more people could be inclined to use city buses and trams - due to the absolute fare free of charge, also for passenger cars who are usually passengers (not drivers). In the heating season 2019/2020 (until the beginning of March 2020), no free communication was launched, which suggests an improvement in air quality. This fact should be associated with the entry into force on September 1, 2019, of a total ban on heating buildings with coal and wood (including burning in fireplaces and stationary grills) in the city of Cracow [6].

Table 3 presents the basis for launching free communication for individual days. In each case, the analysis showed the change in the average daily concentration of PM10 dust, nitrogen oxide and carbon monoxide averaged from all measuring stations on three consecutive days: the day with free public transport and the day before and after its launch. The measurement results are presented in Table 4.

Tab. 3. The basis for launching free public transport. Source: own study based on data from the Public Transport Authority in Cracow

\begin{tabular}{|l|l|}
\hline day & $\begin{array}{l}\text { the basis for starting fare-free } \\
\text { communication }\end{array}$ \\
\hline 11.11 .2018 & IMGW forecast from the previous day \\
\hline 12.13 .2018 & IMGW forecast from the previous day \\
\hline 12.17 .2018 & IMGW forecast from the previous day \\
\hline 12.20 .2018 & IMGW forecast from the previous day \\
\hline 01.21 .2019 & $\begin{array}{l}\text { early morning readings of PM10 dust } \\
\text { concentration }\end{array}$ \\
\hline 01.21 .2019 & IMGW forecast from the previous day \\
\hline
\end{tabular}

In four cases, the concentration of PM10, on the one hand, increases on the day with free public transport, but on the other hand, is lower the next day. Only in one case was there a general decrease in PM10 concentration only on the 'free' day (11/11/2018). Also once there is a systematic decrease in the three-day observation (January 21-23, 2019), however, it should be borne in mind that at that time fare- free travel was offered two days in a row.

On $11 / 11 / 2018$, the concentration of nitrogen oxide is lower than the day before and the day after. Then, the concentration of these pollutants increased three times on the day of free transport, and a systematic decrease twice over three days. Carbon monoxide concentrations, with decreasing or increasing tendencies, behave in the same way as nitrogen oxide. Only in the first observation (November 10-12, 2018), they remain at a similar level for three days.

Taking into account the above observations, it can be seen that the concentration of nitrogen oxide and carbon monoxide in the air changes analogously to each other. This is due 
to their belonging to the same group - pollutants, the main emitter of which is transport. Their decrease or increase most often coincides with a decrease or increase in the concentration of PM10, which is mainly caused by "low emissions".

Tab. 4. Change in the average daily concentration of PM10 dust, nitrogen oxide and carbon monoxide on the day with free public transport and the day before and after its launch. Source: own study based on data from [5]

\begin{tabular}{|c|c|c|c|c|}
\hline \multirow{2}{*}{$\begin{array}{c}\text { fare-free } \\
\text { communication }\end{array}$} & \multicolumn{3}{|c|}{ pollutant concentration } & \multirow{2}{*}{ observations } \\
\hline & day before & that day & day after & \\
\hline \multicolumn{5}{|c|}{ PM10 $\left[\mu \mathrm{g} / \mathrm{m}^{3}\right]$} \\
\hline 11.11 .2018 & 99 & 85 & 92 & fall on the "fare-free" day \\
\hline 12.13 .2018 & 35 & 70 & 33 & $\begin{array}{l}\text { increase on the "fare-free" } \\
\text { day }\end{array}$ \\
\hline 12.17 .2018 & 50 & 122 & 102 & $\begin{array}{l}\text { increase on the "fare-free" } \\
\text { day }\end{array}$ \\
\hline 12.20 .2018 & 63 & 75 & 52 & $\begin{array}{l}\text { increase on the "fare-free" } \\
\text { day }\end{array}$ \\
\hline 01.21 .2019 & 113 & 144 & 124 & $\begin{array}{l}\text { increase on the "fare-free" } \\
\text { day" }\end{array}$ \\
\hline 01.22 .2019 & 144 & 124 & 46 & systematic decline \\
\hline \multicolumn{5}{|c|}{ nitrogen oxide $\left[\mu \mathrm{g} / \mathrm{m}^{3}\right]$} \\
\hline 11.11.2018 & 248 & 223 & 252 & fall on the "fare-free" day \\
\hline 12.13 .2018 & 108 & 131 & 88 & $\begin{array}{l}\text { increase on the "fare-free" } \\
\text { day }\end{array}$ \\
\hline 12.17 .2018 & 132 & 255 & 206 & $\begin{array}{l}\text { increase on the "fare-free" } \\
\text { day }\end{array}$ \\
\hline 12.20 .2018 & 78 & 140 & 270 & systematic growth \\
\hline 01.21 .2019 & 111 & 136 & 103 & $\begin{array}{l}\text { increase on the "fare-free" } \\
\text { day }\end{array}$ \\
\hline 01.22 .2019 & 136 & 103 & 59 & systematic decline \\
\hline \multicolumn{5}{|c|}{ carbon monoxide $\left[\mu \mathrm{g} / \mathrm{m}^{3}\right]$} \\
\hline 11.11 .2018 & 1716 & 1626 & 1631 & on a similar level \\
\hline 12.13 .2018 & 826 & 862 & 642 & $\begin{array}{l}\text { increase on the "fare-free" } \\
\text { day }\end{array}$ \\
\hline 12.172018 & 909 & 1736 & 1411 & $\begin{array}{l}\text { increase on the "fare-free" } \\
\text { day }\end{array}$ \\
\hline 12.20 .2018 & 871 & 1203 & 1336 & systematic growth \\
\hline 01.21 .2019 & 1179 & 1284 & 1150 & $\begin{array}{l}\text { increase on the "fare-free" } \\
\text { day }\end{array}$ \\
\hline 01.22 .2019 & 1284 & 1150 & 535 & systematic decline \\
\hline
\end{tabular}

\section{Summary}

About 45,000 people die in Poland every year due to air pollution [3]. Therefore, there is no doubt that both central and local authorities should take further steps to improve air quality in the country. The example of Krakow as the Polish leader in anti-smog activities shows how difficult this fight is. One of the steps in this direction was to be fare-free public transport during the smog. The start-up procedure was based on the forecasts and actual PM10 concentrations in the air. In practice, however, the main source of this pollution is the so-called low emissions, while transport in this case mainly contributes to the so-called secondary dusting, i.e. raising 
dust already settled on the road [10]. This is confirmed by the results of measurements of PM10 concentrations: there is no constant dependence of changes in these values in relation to the payment (or not) of public transport (Table 4). In some cases, PM10 pollution levels even increase on toll-free driving days.

However, in the case of carbon monoxide and nitrogen oxide, which belong to the group of transport pollutants, the situation is similar. Therefore, there is no sufficient justification for a possible change in the parameters on which the launch of free public transport would depend if it were to continue to function, which in turn seems very likely in view of the pressure of proecological ideas undertaken by the city. Unfortunately, there are no observations of changes in the number of passengers, but there is no basis to claim that drivers on a mass scale give up the involvement of their vehicles. It should be noted that the possible increase in the occupancy of trams and buses may result not only from the resignation from travelling by passenger cars but also from the unfavourable substitution of pedestrian crossings, bicycle rides or personal transport devices (UTO). It should be emphasized that further research is justified, both on the sources of pollution and their periodic changes, and on the impact of remedial measures, such as free public transport, on air quality.

\section{Source materials}

[1] Diagnoza stanu środowiska miasta Krakowa - załącznik do Programu ochrony środowiska dla miasta Krakowa na lata 2012-2015 z uwzględnieniem zadań zrealizowanych w 2011 roku oraz perspektywą na lata 2016-2019.

[2] Kompleksowe Badania Ruchu w Krakowie. Badania zachowań komunikacyjnych mieszkańców Krakowskiego Obszaru Metropolitarnego. Raport końcowy z badań ankietowych wraz z syntezą wyników i szczegółowymi wnioskami. Kraków, maj 2014.

[3] Malasek J., Ograniczanie emisji w transporcie drogowym, „Transport Miejski i Regionalny", 2017, nr 10, strony 3-4.

[4] Program ochrony środowiska dla miasta Krakowa na lata 2012-2015 z uwzględnieniem zadań zrealizowanych w 2011 roku oraz perspektywą na lata 2016-2019.

[5] System monitoringu jakości powietrza Wojewódzkiego Inspektoratu Ochrony Środowiska w Krakowie, http://monitoring.krakow.pios.gov.pl/ (dostęp: 11.03.2020).

[6] Uchwała Nr XVIII/243/16 Sejmiku Województwa Małopolskiego z dnia 15 stycznia $2016 \mathrm{r}$.

[7] Uchwała $\mathrm{Nr}$ XXXIV/578/15 Rady Miasta Krakowa z dnia 16 grudnia 2015 r. z późniejszymi zmianami.

[8] Urbanek A., Czy bezpłatny transport miejski przekona pasażerów do rezygnacji z samochodu osobowego?, „Komunikacja Publiczna”, 2017, nr 4(69), strony 30-35.

[9] Uzasadnienie do Zarządzenia Nr 1445/2018 Prezydenta Miasta Krakowa z dnia 08.06.2018 r.

[10] Wojtal R., Zanieczyszczenie powietrza $w$ miastach $w$ aspekcie ruchu samochodowego, „Transport Miejski i Regionalny”, 2018, nr 01, strony 12-17. 